University of Nebraska - Lincoln

DigitalCommons@University of Nebraska - Lincoln

Papers in the Earth and Atmospheric Sciences

Earth and Atmospheric Sciences, Department

\title{
Tracking Holocene Climatic Change with Aquatic Biota from Lake Sediments: Case Studies of Commonly Used Numerical Techniques
}

\author{
Brian F. Cumming \\ Queen's University, Kingston, ON, brian.cumming@queensu.ca \\ Kathleen R. Laird \\ Queen's University, Kingston, ON, lairdk@queensu.ca \\ Sherilyn C. Fritz \\ University of Nebraska-Lincoln, sfritz2@unl.edu \\ Dirk Verschuren \\ Ghent University, Belgium, dirk.verschuren@ugent.be
}

Follow this and additional works at: https://digitalcommons.unl.edu/geosciencefacpub

Cumming, Brian F.; Laird, Kathleen R.; Fritz, Sherilyn C.; and Verschuren, Dirk, "Tracking Holocene Climatic Change with Aquatic Biota from Lake Sediments: Case Studies of Commonly Used Numerical Techniques" (2012). Papers in the Earth and Atmospheric Sciences. 389.

https://digitalcommons.unl.edu/geosciencefacpub/389

This Article is brought to you for free and open access by the Earth and Atmospheric Sciences, Department of at DigitalCommons@University of Nebraska - Lincoln. It has been accepted for inclusion in Papers in the Earth and Atmospheric Sciences by an authorized administrator of DigitalCommons@University of Nebraska - Lincoln. 
Published (as Chapter 20) in H.J.B. Birks, et al., eds., Tracking Environmental Change Using Lake Sediments, pp. 615-642; Developments in Paleoenvironmental Research 5; doi: 10.1007/978-94-007-2745-8 20

Copyright (C) 2012 Springer Science+Business Media B.V. Used by permission.

\title{
Tracking Holocene Climatic Change with Aquatic Biota from Lake Sediments: Case Studies of Commonly Used Numerical Techniques
}

\author{
Brian F. Cumming, ${ }^{1}$ Kathleen R. Laird, ${ }^{1}$ \\ Sherylyn C. Fritz, ${ }^{2}$ and Dirk Verschuren ${ }^{3}$
}

1. Paleoecological Environmental Assessment and Research Laboratory (PEARL), Department of Biology, Queen's University, Kingston, ON K7L 3N6, Canada; email brian.cumming@queensu.ca \& lairdk@queensu.ca

2. Department of Earth and Atmospheric Sciences, University of Nebraska-Lincoln, Lincoln, NE 68588-0340, USA; email sfritz2@unl.edu

3. Limnology Unit, Department of Biology, Ghent University, KL Ledeganckstraat 35, B-9000, Ghent, Belgium; email dirk.verschuren@ugent.be

\begin{abstract}
It is now widely recognized that reliable long-term climatic data are required to evaluate the impact of human activities on climate. Lake-sediment records are an important source of such paleoclimatic information, on timescales from years to millennia. However, unequivocal interpretation of biological climate-proxy data preserved in lake sediments can be very challenging. Here we review the different numerical approaches that are used to evaluate the sensitivity and reliability of species assemblages of aquatic biota (algae and invertebrates) extracted from lake-sediment records as proxies of past climatic conditions. The most common techniques used to assess this relationship between these proxies and climate include calibration functions that model the relationship across modern lake environments between species composition in the indicator group and particular climate-influenced aspects of their aquatic habitat, and assessments of the main directions of variation in species composition in relation to independent climatic data. Other statistical techniques, such as variation partitioning analysis, are used to assess the relative importance of climate versus other factors in influencing limnological changes seen in the sedimentary record. These techniques show that in climate-sensitive lake systems, the sedimentary remains of aquatic biota can be sensitive and trustworthy proxies, permitting quantitative reconstructions of past climatic conditions with high temporal resolution.
\end{abstract}


Keywords: Calibration functions, Chironomids, Climatic change, Diatoms, Invertebrates, Modern analogues, Ordination, Paleoclimate, Rate-of-change analysis, Reconstruction validation, Variation partitioning

\section{Introduction}

With recent concerns about global change, the need for reliable long-term paleoclimatic data is now universally recognized by governments and international organizations. Such records are necessary to provide information on the magnitude and patterns of past climatic change against which recent changes can be assessed. Furthermore, prognoses of future climatic conditions will be enhanced when we better understand the temporal and spatial patterns of natural climatic variability.

Historically, a great amount of information on long-term climatic variability has been provided by reconstructions of past vegetation changes from pollen and plant macrofossils preserved in lake sediments (e.g., Webb 1986; Prentice et al. 1991) and from studies applying geomorphological, sedimentological, and biostratigraphical methods to transects of sediment cores to reconstruct changes in water level (e.g., Harrison and Digerfeldt 1993). However, as noted by many authors (e.g., Ritchie 1987), pollen-based studies have certain limitations, which include the inability to identify many pollen taxa below the family level; the broad dispersal of many windblown pollen grains; the differential response of various tree species to climatic change associated with variation in topography, soils, lifecycle characteristics, and anthropogenic factors; and the general scarcity of pollen and macrofossils in some environments (e.g., regions at high altitudes and/or latitudes). None-the-less, contributions from palynological and lake-level studies have elucidated the broad-scale temporal and spatial template of climatic change in many regions, and in some regions have the potential to provide records of climatically-driven vegetation change with high temporal resolution (e.g., Clark et al. 2002; Lamb et al. 2003; Gajewski 2008; Kröpelin et al. 2008; St. Jacques et al. 2008a, 2008b).

Many lakes exhibit physical, chemical, and/or biological responses to changes in climatic conditions, and evidence of these changes are often preserved in their sediment record (Battarbee 2000; Smol and Cumming 2000; Fritz 2008). Analyses of the remains of aquatic algae (e.g., diatoms, chrysophytes, pigments) and invertebrates (e.g., chironomids, cladocerans, ostracods) in sediment cores from such climatically-sensitive lakes can potentially provide records of climatic and environmental change at a higher resolution than most palynological and many lake-level studies. Enhanced sensitivity of aquatic biological indicators (proxies) to environmental change is due to our ability to identify many of these organisms to species level, their short life-span, and their fast dispersal, which guarantees rapid colonization of newly available habitat and thus avoids significant lags in their response to climatic change. Thus, examination of changes in the species 
composition of aquatic biota in sediment cores can provide valuable insights into how climatic conditions have varied in the past that may not be readily apparent from terrestrial indicators. However, the relative importance of climatic change can be complex, even in apparently simple aquatic systems (e.g., Anderson et al. 2008; Fritz 2008).

In this chapter, we provide an overview of the different numerical techniques that have been used to study the linkages between changes in biotic assemblages preserved in lake sediments and climatic change during the Holocene. It is important to note that these approaches are simply tools that are useful to assess, simplify, and visualize past environmental changes in a repeatable and somewhat objective manner. Many studies make limited use of numerical approaches but still yield valuable insights into past climatic conditions (e.g., Baker et al. 2001; Bennett et al. 2001; Dean 2002; Dean et al. 2002; Spooner et al. 2002). Finally, although the focus of this chapter is on approaches that have been used to interpret climatic signals in fossil assemblages of lake biota, equally important paleoclimatic information is derived from physical (e.g., Lamoureux 2000; Noon et al. 2001; Dean et al. 2002; Pienitz et al. 2009) and geochemical proxies (e.g., Dean 2002; Tierney et al. 2008; Pienitz et al. 2009; Toney et al. 2010). The latter increasingly include stable-isotope signatures extracted from lake biota, such as ostracods (e.g., von Grafenstein et al. 1999), chironomids (e.g., Verbruggen et al. 2010), and diatoms (e.g., Hernandez et al. 2010).

\section{Biological Proxies of Past Climatic Conditions}

Proxy data based on biotic assemblages preserved in lake sediments have long been known to be sensitive and reliable indicators of past climatic change, because of the strong influence of temperature and rainfall variations on the structure and function of their aquatic habitats. Lake characteristics that are sensitive to climatic changes can be both physical (e.g., temperature, ice cover, lake depth, river discharge, mixing regime, light transparency) and chemical (e.g., changes in alkalinity, pH, nutrients, salinity) (e.g., Walker et al. 1991; Walker 1995; Vinebrooke et al. 1998; Korhola 1999; Battarbee 2000; Smol and Cumming 2000; Korhola and Rautio 2001; Brodersen and Anderson 2002; Fritz 2008; Lotter et al. 2010; Wolin and Stone 2010).However, establishing an unequivocal connection of these limnological changes to climate is often difficult. The challenge is to demonstrate that the biotic proxy indicators are connected to climate in a systematic, predictable fashion. In some systems, this is exceedingly difficult because of the non-linear responses of the limnological system to climatic change and subsequent sedimentological complications, such as variable sedimentation rates and/ or mixing (Verschuren 1999a, 1999b). Such complexities are related to basin hydrology, as well as to the physical, chemical, and biological characteristics of individual lake basins (Smol and Cumming 2000; Schwalb and Dean 2002; Fritz 2008). Additionally, because different groups of biological proxies have different life- 
history strategies, changes in climate that influence aquatic systems can impact various proxies in different ways (Battarbee et al. 2002a; Heegaard et al. 2006). Therefore, it is not surprising that the response of different lakes, and of different proxies within a single lake, to climatic change can vary tremendously (Smol and Cumming 2000; Fritz 2008).

Successful paleoclimatic interpretation of in-lake biological proxies depends on a good understanding of the climatic response of a lake to changes in climate. Not surprisingly, selecting and then demonstrating the climatic sensitivity of a site is not a simple procedure. Smol and Cumming (2000) identified lakes that are thought to be especially sensitive. These include lakes from high latitudes, lakes that are close to ecotonal boundaries (e.g., near tree-line, near the forestprairie boundary), and lakes in arid to semi-arid regions with limited groundwater inputs and, ideally, large catchments (i.e., amplifier lakes: Olaka et al. 2010). In addition to geographical position, sites sensitive to climatic changes can be identified from measurements of limnological change (e.g., changes in lake-water chemistry, transparency, declines in water levels, and/or changes in salinity) and from instrumental and/or historical records (Fritz 1990; Schindler et al. 1996; Verschuren 1996, 2003; Webster et al. 2000; Doran et al. 2002). However, data of sufficient duration and frequency are relatively rare, even in populated regions. Additional information on the hydrological responsiveness to changes in climatic conditions can be obtained by careful examination of temporal sequences of aerial photographs and satellite images (Donovan et al. 2002; Smith et al. 2005).

Once climate-sensitive lakes have been identified, it is becoming increasingly common to assess the strength of the climatic impact on biological proxies or inferred limnological variables in the sediment record by comparison of the proxy records with instrumental meteorological data (temperature, precipitation, drought indices), historical data of lake response to climate (e.g., lake-level changes, chemical constituents), or with independent evidence of climatic change (e.g., documentary, other paleoclimatic proxies). These comparisons may involve simple visual matching of pattern similarities in the paleolimnological and meteorological records, calculation of correlation coefficients between lake and climatic variables, or using multivariate numerical methods (e.g., variation partitioning: Borcard et al. 1992; Legendre and Birks 2012: ch. 8).

\section{Comparison of Inferred Limnological Variables and Instrumental Climate Data}

In arid to sub-humid regions, long-term (decade-scale and longer) variations in the balance of rainfall and evaporation can drive significant changes in lake level, which in turn may influence the physical, chemical, and biological environment of lakes to the extent that their signatures are recorded in the sedimentary record (Fritz 1996). In other regions, the influence of temperature is evident in the sedimentary record, either directly or indirectly, via changes in catchment 
Figure 1. Diatom-inferred salinity estimates from Moon Lake (North Dakota, USA) (solid line) compared to a smoothed BhalmeMooley Drought Index (dotted line) based on nearby instrumental precipitation records over the last 100 years; $r=0.49, p<$ 0.01. (Modified from Laird et al. 1998a.)

\section{Bhalme Mooley Drought Index}

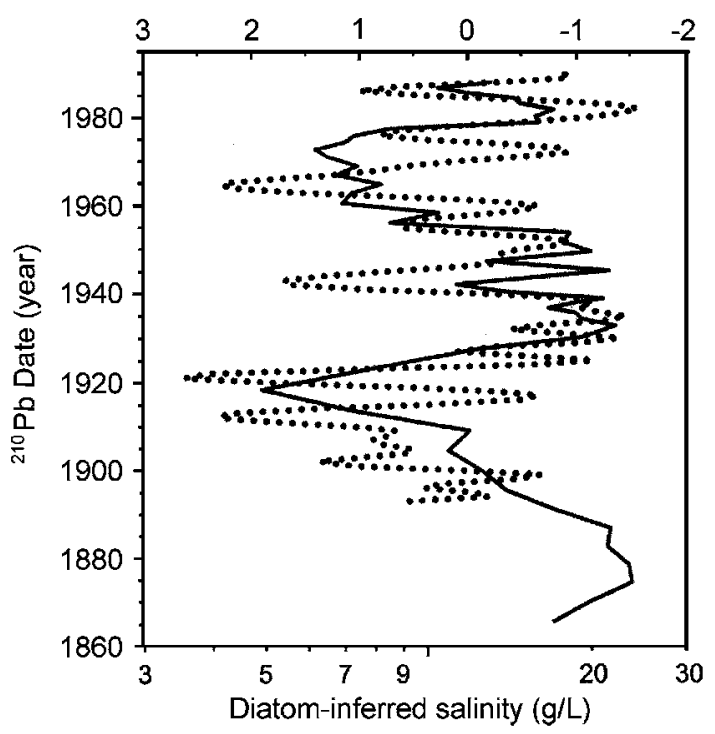

hydrology, vegetation, ice cover, or mixing regimes. One way to validate proxybased climatic inferences is to compare quantitatively or qualitatively the proxybased reconstructions of environmental change (e.g., lake-water salinity, lake level, temperature) in the recent past with historical time-series of instrumental meteorological data. To date, the majority of such direct, quantitative comparisons have used approaches based on calibration functions (see Juggins and Birks 2012: ch. 14).

To evaluate the climatic sensitivity of Moon Lake (Northern Great Plains, USA), Laird et al. (1996a) assessed the correlation between diatom-inferred (DI) salinity through time in a ${ }^{210} \mathrm{~Pb}$-dated sediment core and instrumental time-series of effective moisture (precipitation minus evapotranspiration or ET). Diatom-inferred salinity showed major increases coincident with the major droughts of the 1930s and the 1890s, with a statistically significant relationship between DI salinity and effective moisture (Laird et al. 1996a). Because ET can be difficult to estimate, Laird et al. (1998a) replaced estimates of effective moisture with the Bhalme and Mooley drought index (BMDI), derived from nearby precipitation records (Figure 1). The BMDI was chosen as a measure of drought, because it is based on precipitation records from local stations, as opposed to regional precipitation averages used in some other indices, such as the Palmer Drought Severity Index. In this analysis, the BMDI was smoothed using a four-point Fourier transform filter to achieve approximately equal time resolution between the sediment record and the instrumental data. A modest correlation between diatom-inferred salinity and BMDI (Figure 1) can be attributed to several factors, including the low time resolution in core data from before 1940, the further distance of the meteorological station from the lake for the early instrumental period, and limnological changes that are potentially attributable to settlement and agricultural 


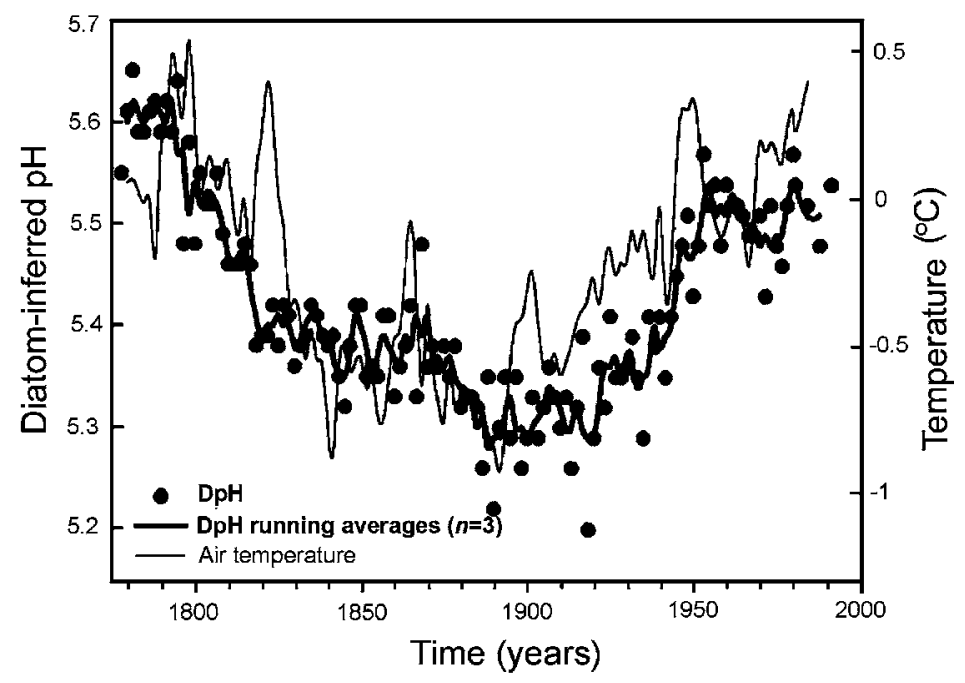

Figure 2. Diatom-inferred lake-water pH from Schwarzsee ob Sölden in the Austrian Alps since $\sim 1780$ compared with smoothed annual mean air temperature from 20 regional weather stations; $r=0.68, p<0.001$. (From Sommaruga-Wögrath et al. 1997, with permission.)

practices that may have impacted lake chemistry independent of climate since the early 1900s. Comparison of the Moon Lake record with regionally recognized climatic anomalies prior to the instrumental record (e.g., a tree-ring inferred wet period from 1825 to 1838 and the extreme 1890s drought) suggest, however, that the diatom-inferred salinity record does capture the general drought trends characteristic for the Northern Great Plains (Laird et al. 1996a, 1998a, 1998b). Consequently, this site was chosen to reconstruct drought intensity, duration, and frequency throughout the Holocene at both centennial and sub-decadal scales (Laird et al. 1996a, 1996b, 1998a, 1998b).

In a study from a mountain lake in the Austrian Alps, comparison between diatom-inferred $\mathrm{pH}$ and instrumental air temperature between 1778 and 1991 revealed a significant positive correlation $(r=0.68, p<0.001)$ (Figure 2) (Sommaruga-Wögrath et al. 1997), suggesting that diatoms may be an important proxy of past temperatures. In two other alpine lakes, diatom-inferred $\mathrm{pH}$ and temperature were correlated during the entire 19th century, but the relationship weakened during the 20th century with the onset of acidic deposition (Psenner and Schmidt 1992). The mechanism that produced the $\mathrm{pH}$ increases during warming events and declines during cooler periods is likely to be related to changes in the duration and extent of ice-cover because these would alter light, temperature, and nutrient regimes, all of which affect diatom production and could influence in-lake production of alkalinity, as well as lake-water $\mathrm{pH}$ (Sommaruga-Wögrath et al. 1997). Periods of prolonged ice-cover would also reduce $\mathrm{CO}_{2}$ exchange with the atmosphere and temporarily eliminate atmospheric inputs of base cations into the lake (Psenner and Schmidt 1992), both of which would affect the acidbase status in poorly-buffered lakes. 
Bigler and Hall (2003) and Larocque and Hall (2003) compared chironomid and diatom-inferred mean-July air temperatures from northern Swedish sediment cores over the last century to measured values from nearby meteorological stations. In all four lakes studied, chironomid-inferred July temperatures were significantly but weakly correlated to the instrumental record ( $r=0.35-0.39)$. The relationship between diatom-inferred and instrumental July temperatures was weaker, and no correlation coefficients or levels of significance were reported.

Many studies have validated climate proxies through a qualitative comparison of reconstructed environmental change to historically documented changes in climatically-sensitive limnological variables, an approach first used in comparisons of diatom-inferred salinity and ostracod trace-metal content with documented changes in the depth and salinity of Devils Lake (Northern Great Plains, USA) (Fritz 1990; Engstrom and Nelson 1991). One particular series of studies (Verschuren 1999a, 1999b, 2001; Verschuren et al. 1999a, 1999b, 2000a) investigated the sedimentological, geochemical, and biological signatures of climatically driven lake-level changes in a system of four contrasting lakes in the Eastern Rift Valley of Kenya, which because of their hydrological inter-connectedness have a common recorded lake-level history spanning the last 120 years (Verschuren 1996). Together these studies illustrate the complexity of chemical and biological responses to climatically-driven changes in water balance at sub-decadal time scales (Verschuren et al. 1999a, 1999b, 2000a), and how the signatures of this response in the sediment record are affected by sedimentation dynamics and taphonomy (Verschuren 1999a; Verschuren et al. 1999a). For example, although reconstructed salinity and lake-level changes in Lake Oloidien displayed the expected inverse relationship, this was modulated by delayed dilution of residual salts following a modest lake-level rise in the late 1950s and early 1960s (Figure 3) (Verschuren et al. 2000a). In nearby Lake Sonachi, diatoms quickly responded to a major 1890s lake-level rise which created stable density stratification of the water column. In the sediment record, however, their response is delayed by almost a decade because previously buried shallow-water diatoms are re-deposited in deep-water sediments during the transgression (Verschuren et al. 1999b). In the three main groups of aquatic invertebrates present (ostracods, cladocerans, chironomids), only some species responded directly to salinity change (via the physiological impact of osmotic stress). Most species responded more strongly to substrate changes associated with the lake-level change itself or to changes in the distribution of aquatic vegetation (Verschuren et al. 2000a). While lake depth, salinity, and substrate quality are all important factors in structuring aquatic invertebrate communities, it is sobering to realize that at the time-resolution of many modern paleoclimatic studies, the intuitive co-variation between these factors can be strongly modulated by transient system dynamics. None-the-less, invertebrate communities do remain useful proxies of past hydrological change, particularly in combination with diatoms and non-biological climatic proxies. Other qualitative studies (e.g., Legesse et al. 2002) have used both biological and sedimentological proxies to reveal fluctuations in water depth and salinity that are broadly consistent with available instrumental and historical records. 


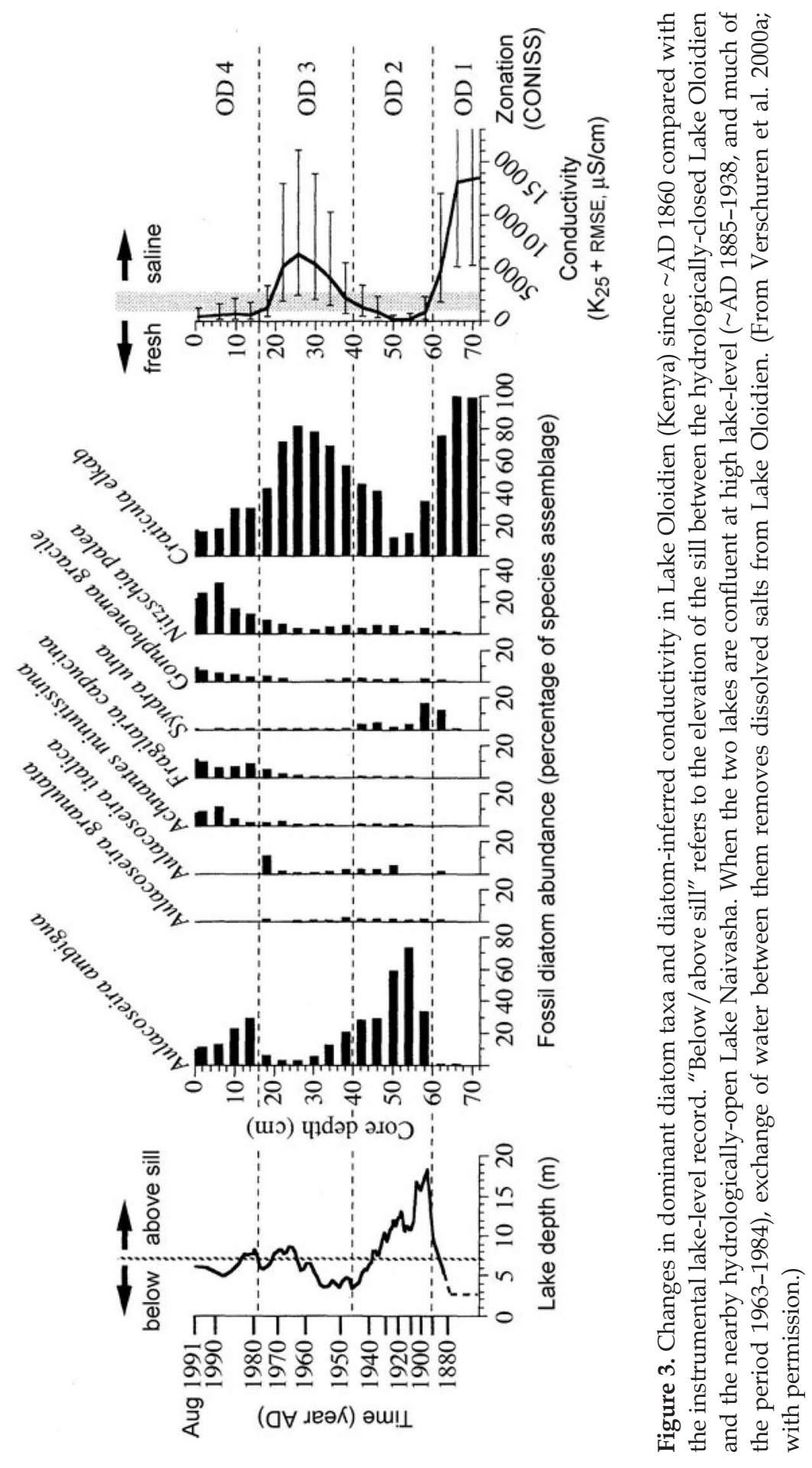


Although direct comparison of paleoclimatic reconstructions with meteorological data has yielded many valuable insights into the response of specific lakes to climatic variation, other approaches may be used. These include comparisons between the main directions of variation in fossil assemblages and instrumental climatic records (Sorvari et al. 2002), the use of variation partitioning to assess the role of climate in proxy records over the instrumental period (Lotter and Birks 1997; Hall et al. 1999; Quinlan et al. 2002), and comparisons of within-lake proxy records with independent estimates of climatic change (Anderson et al. 1996, 2008; Stager et al. 1997; Cumming et al. 2002; Wolfe 2003; Enache and Cumming 2009; Stone et al. 2011).

\section{Direct Comparison of Biological Data to Instrumental Climatic Data}

Ordination techniques (see Legendre and Birks 2012: ch. 8) are now widely used to quantify and summarize the main directions of variation in biological assemblages (Cumming and Moser 2007), which can then be correlated directly to instrumental climatic records. For example, Sorvari et al. (2002) examined the relationship between species-composition changes in the diatom communities of five lakes with varying characteristics in Finnish Lapland over the last 200 years using principal component analysis (PCA), a common ordination technique (Figure 4). The PCA sample scores from each lake record were highly correlated to each other ( $r=0.74-0.95)$, as well as being significantly correlated to instrumen-

Figure 4. (a) Trends in principal component analysis (PCA) axis-1 sample scores of fossil diatom floras in five lakes from Finnish Lapland over the last 200 years in relation to $(\mathbf{b})$ smoothed spring temperature anomalies $\left({ }^{\circ} \mathrm{C}\right)$. (Modified from Sorvari et al. 2002.)
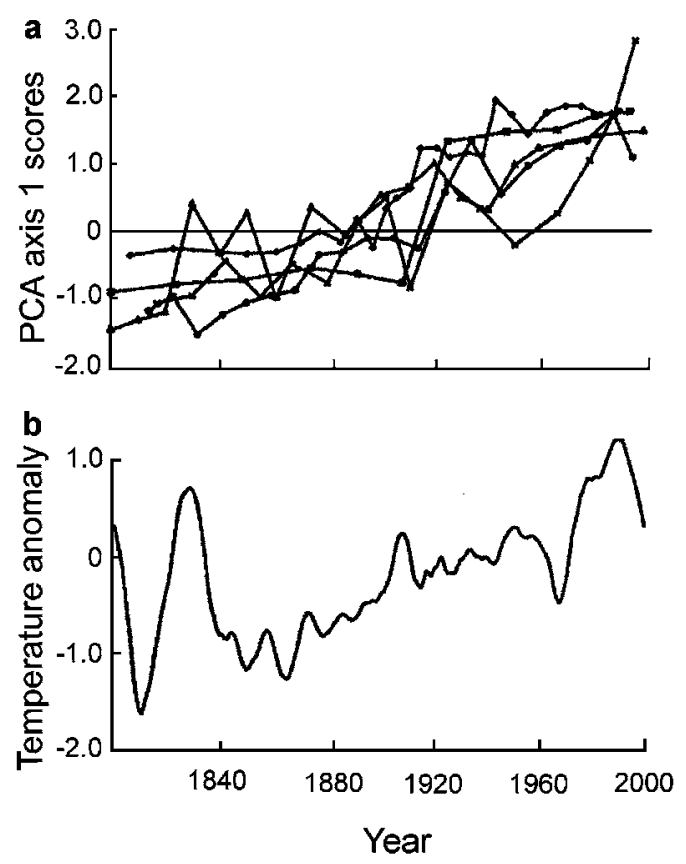
tal records of yearly temperature $(r=0.39-0.62$ in three of the five lakes investigated). Interestingly, the highest correlations $(r=0.52-0.70)$ were between the main direction of variation in the diatom assemblages and spring temperatures. Sorvari et al. (2002) suggested that the strong coherence of sedimentary signatures in these five lakes, and their significant correlation with temperature change over the last $\sim 200$ years, indicate that diatom floras did indeed respond to regional temperature rise, possibly through decreased ice-cover, a longer growingseason, or enhanced thermal stratification. This example illustrates that arctic as well as alpine lakes are sensitive locations to search for ecosystem changes in response to recent climatic change (Battarbee et al. 2002a; Heiri and Lotter 2005; Smol et al. 2005: Lotter et al. 2010). The response of these systems to climate is not limited to direct temperature influences, but may also include responses to changes in physical and chemical aspects of the aquatic environment, which themselves are affected by changes in temperature or precipitation. For example, such changes may include the duration of ice-cover, microhabitat availability, and changes in dissolved organic carbon (DOC) or acid-base status (Smol and Cumming 2000; Smol and Douglas 2007; Lotter et al. 2010).

In a large interdisciplinary study involving seven European high-elevation lakes, the Mountain Lake Research (MOLAR) project, researchers sought to establish links between various biotic and abiotic proxies in lake sediments and instrumental temperature records (summarized by Battarbee et al. 2002a). The biological proxy indicators included assemblages of diatoms, chrysophytes, chironomids, and cladocerans. Potential explanatory variables included: mean summer temperature (June to August and July to September), mean winter temperature (December to February), an index of continentality (difference between June to August and December to February), and mean annual temperature (average of all 12 months). Because instrumental data series directly linked to these remote high-elevation sites were not long enough for comparison with core data, homogenized lowland air-temperature records were transformed to values appropriate for each high-elevation site using the contemporary relationship between lowland temperatures and recently established on-site automatic weather stations (Agusti-Panareda and Thompson 2002). Prior to regression analysis, the variation in each of the biotic proxy data-sets was numerically reduced to its main direction of variation by calculating sample scores along PCA axes, following a square-root transformation of the species percent-abundance data. Correlations between the main direction of variation in the biological data and the instrumental records were very low, with few clear or consistent patterns. The highest correlations were found using the greatest smoothing of the instrumental data, suggesting that the biological proxy data may capture only the broadest, long-term changes in these records. Planktonic diatom assemblages (at most sites) and chrysophytes and chironomids (at a few sites) showed the highest correlation with the instrumental data (Battarbee et al. 2002b; Koinig et al. 2002). The generally weak correlations were mainly attributed to inaccurate dating and/or the limited sensitivity of some proxies to modest recent climatic forcing, as well 
as confounding forcing factors, such as air pollution and earthquakes, at some sites. These results are perhaps not surprising, because different species thrive at different locations within the lake as well as at different times in the season (e.g., Interlandi et al. 1999; Bradbury et al. 2002; Catalan et al. 2002). Consequently, the use of yearly averages or average temperature in any given season will likely fail to represent accurately the ecological characteristics of some of the species to temperature. The low correlations found in this study in comparison to the five sites in Finnish Lapland may also suggest that the lakes in the MOLAR project were not as sensitive to recent climatic changes or that the degree of climatic change has been less in the MOLAR lakes in comparison to those in Lapland. Continued investigation of the response of varied proxies and European lakes to climate is ongoing in the large interdisciplinary European Millennium Project (e.g., von Gunten et al. 2008), which is focused on reconstructing regional climates of the last 1000 years.

\section{Assessing the Influence of Climate on Lake History Using Variation Partitioning and Linear Mixed-Effects Models}

Variation partitioning analysis (VPA) has been used increasingly to assess the relative influence of climate versus other factors in driving limnological changes reconstructed from the sedimentary record. Variation partitioning (Borcard et al. 1992; Legendre and Birks 2012: ch. 8; Lotter and Anderson 2012: ch. 18; Simpson and Hall 2012: ch. 19) uses direct gradient analysis or canonical ordination to estimate which fraction of the total variation in assemblage composition can be explained by specific categories of measured environmental variables, and which fraction is shared between different categories of variables. For example, Lotter (1998) used VPA to estimate the amount of variance in diatom data from a 100+year varved sediment record from Baldeggersee (Switzerland) that could be explained independently by trophic state and climate (also see Lotter and Anderson 2012: ch. 18). The variation in the diatom data was partitioned into: (i) variation due to changes in lake trophic state only (modeled by measured and extrapolated total phosphorus, lake restoration, and their interaction); (ii) variation due to climatic change only (modeled by mean spring air temperatures); (iii) covariation between (i) and (ii); and (iv) variation unexplained by the model. Because of strong temporal autocorrelation in the data, the effect of time was removed prior to the statistical analyses. Trophic state and climate together accounted for only $14.2 \%$ of the total variation in the diatom data $(p=0.01)$, with $12.6 \%$ being explained by trophic state $(p=0.06)$, and only $1.1 \%$ by climate $(p=0.08)$. Hence, Lotter (1998) concluded that changes in climatic variables were relatively unimportant in comparison with trophic-state variables in explaining changes in the diatom assemblages. Lotter and Birks (1997) used a similar approach to disentangle the relative importance of trophic state and climate on varve thickness in the same lake. Heiri and Lotter (2005) used variance partitioning to examine the influence of co-variation between sum- 
mer temperature and trophic state on calibration-function development in the Swiss Alps. Their analyses suggest that independent calibration functions can be developed for diatoms and benthic cladocerans but caution should be used in interpreting total phosphorus (TP) reconstructions from chironomids.

Hall et al. (1999) used VPA to determine how much of the down-core variation in diatom, pigment, and chironomid assemblages from Pasqua Lake (Saskatchewan, Canada) could be accounted for solely by climate (C), resource-use (R), urbanization (U), and by covariations between them (i.e., CR, CU, RU, and CRU). Hall et al. (1999) performed separate VPAs on the percent abundances of diatoms and chironomids and a 3-year running mean of pigment concentrations for periods beginning in 1890, 1920, 1950, and 1970, so that the relative importance of climate, resource-use, and urbanization on the biological records could be evaluated through time. All categories, both independently and in combination, explained significant amounts of variation in the biological data, although their relative importance depended on the fossil group and the period considered. Changes in urban population, sewage characteristics, livestock biomass, crop area, and temperature and precipitation proved to be consistently important explanatory variables in the history of this lake (Hall et al. 1999). However, the most consistently important explanatory variable was resource-use, accounting for between $14 \%$ and $25 \%$ of the variation in the fossil assemblages according to the VPAs. Variation attributable solely to climate was consistently low (between $4 \%$ and 10\%), but the covariation between climate and resource-use and urbanization (CR, CU, or CRU) were typically quite large, at times accounting for more than $50 \%$ of the total variation. In a similar study from the Canadian prairies involving eight lakes, Quinlan et al. (2002) found that VPA identified climate (specifically winter temperature) as the category that accounted for the largest amount of variation in past chironomid assemblages (on average $\sim 25 \%$ ), whereas changes in resource-use and urbanization only accounted for $\sim 7 \%$ and $\sim 4 \%$ of variation, respectively. In summary, one of the benefits of VPA is that it potentially allows the relative importance of competing influences to be evaluated and quantified (Birks 1998).

Eggermont et al. (2010a) assessed whether the Rwenzori mountain lakes (Uganda/DR Congo) are sensitive to climate-driven environmental change of the same order of magnitude as that expected to result from current and future anthropogenic global warming. This was done by comparing the species assemblages of larval chironomid remains deposited recently in lake sediments with those deposited at the base of the short cores (dated to within or shortly after the Little Ice Age) in 16 lakes. Chironomid-based temperature reconstructions were made using temperature-inference models (Eggermont et al. 2010b) with calibration functions based on weighted averaging, weighted-averaging partial least squares, or a weighted modern analogue technique (see Juggins and Birks 2012: ch. 14; Simpson 2012: ch. 15). Excluding one atypical mid-elevation lake, Eggermont et al. (2010a) found a three-to-one ratio of sites with inferred warming against inferred cooling. The chironomid-inferred temperature changes mostly fell within the error range of the inference models, but a generalized lin- 
ear mixed-effects analysis (SAS Inc. 2004; Birks 2012: ch. 11) of the combined result nevertheless indicated significantly warmer mean annual air temperature (on average $+0.38 \pm 0.11^{\circ} \mathrm{C}$ ) at present compared to between $\sim 85$ and $\sim 645$ years ago. This result was independent of whether lakes were located in glaciated or nonglaciated Rwenzori catchments, and of basal core age, suggesting that at least part of the signal is due to relatively recent, anthropogenic warming.

\section{Qualitative Validation of Biological Proxies Using Independent Evidence of Climatic Change}

Support for the climatic sensitivity of lake systems is not limited to comparisons with instrumental and other historical data. Lake response to climate also can be assessed by comparisons (qualitative or quantitative) of in-lake climateproxy indicators with other known climatic proxies. For example, Pienitz et al. (1999) assessed changes in diatom species composition in a sediment core from Queen's Lake (Northwest Territories, Canada), located north of the tree-line. Sharp increases in the abundances of black spruce (Picea mariana) pollen and sediment organic matter between $\sim 5000$ and 3000 years ago (Figure 5), in conjunction with isotopic changes, strongly suggested regional climatic warming during this interval (MacDonald et al. 1993; Wolfe et al. 1996). Coincident with these changes were abrupt changes in both the concentration and species composition of diatoms in the sediment profiles (Figure 5). By using a diatom-based calibration function for dissolved organic carbon (DOC), developed from a regional surfacesediment calibration-set (Pienitz et al. 1995), Pienitz et al. (1999) showed that the diatom changes were consistent with changes in lake-water transparency caused by changes in soils as trees moved into the watershed during climatic warming.

Another example of palynological data being used to support inferences of past changes in diatom species composition comes from Lake Victoria, East Africa (Stager et al. 1997). In this study, changes in diatom species composition over the last $\sim 14,000$ years were summarized into two main directions of variation by correspondence analysis (CA) (see Legendre and Birks 2012) (Figure 6). The two main directions of variation were interpreted to represent relative water column stability (or conversely mixing, an index of wind strength) and the ratio of precipitation to evaporation (or effective moisture, assumed to be reflected in lake depth) based on the known habitat requirements of the dominant diatom species found in the fossil record. In conjunction with pollen records of past changes in terrestrial vegetation within the Lake Victoria catchment from an earlier study from a nearby location (Kendall 1969), the diatom data permitted the delimitation of four major periods of limnological/climatic change over the past 14,000 years: (1) a period of aridity, from $\sim 13,400$ to 11,400 cal year. BP, represented by extremely high abundances of Fragilaria and other benthic diatoms coincident with the abundant occurrence of grass pollen and phytoliths; (2) an early-Holocene humid phase characterized by high abundances of 

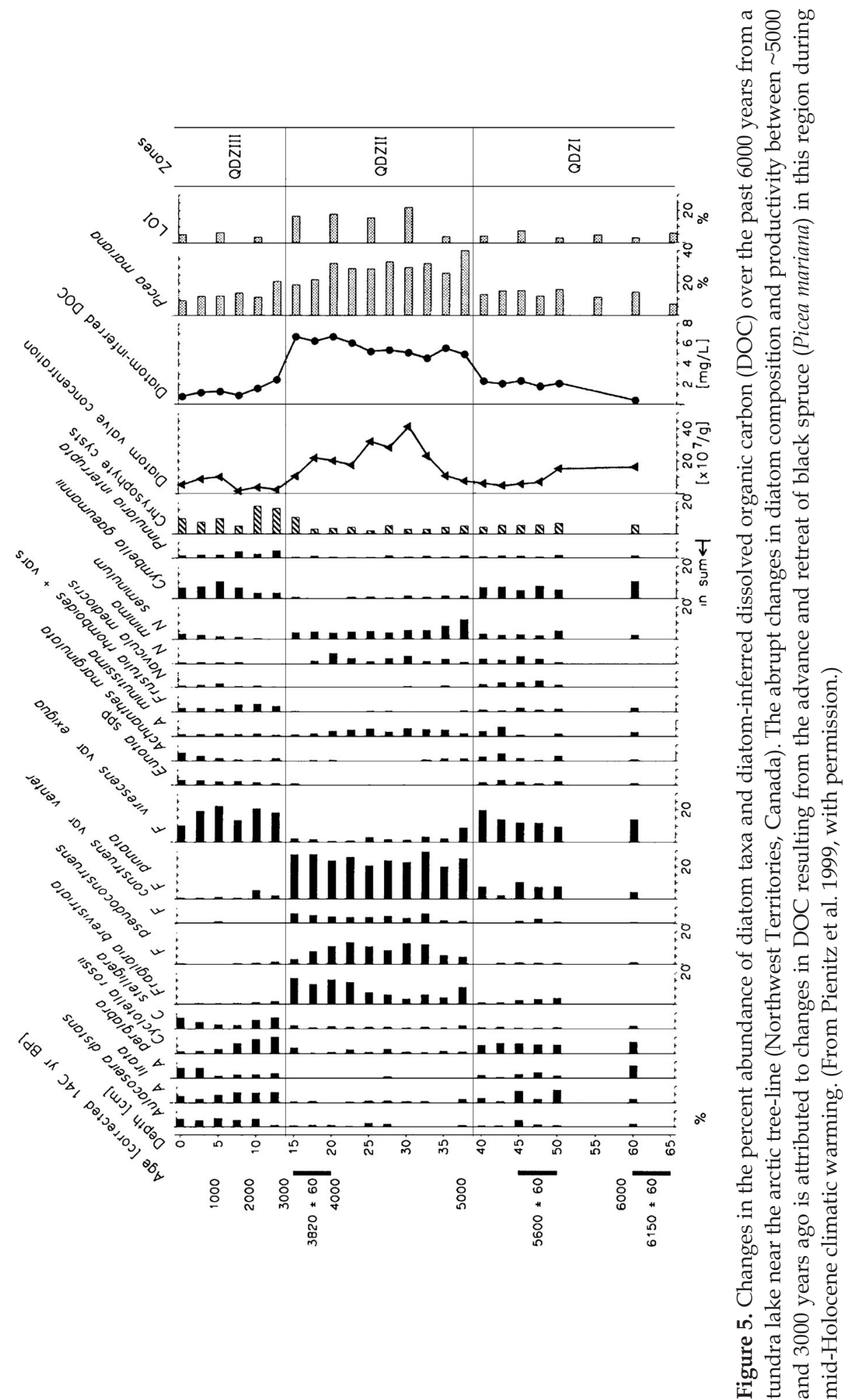


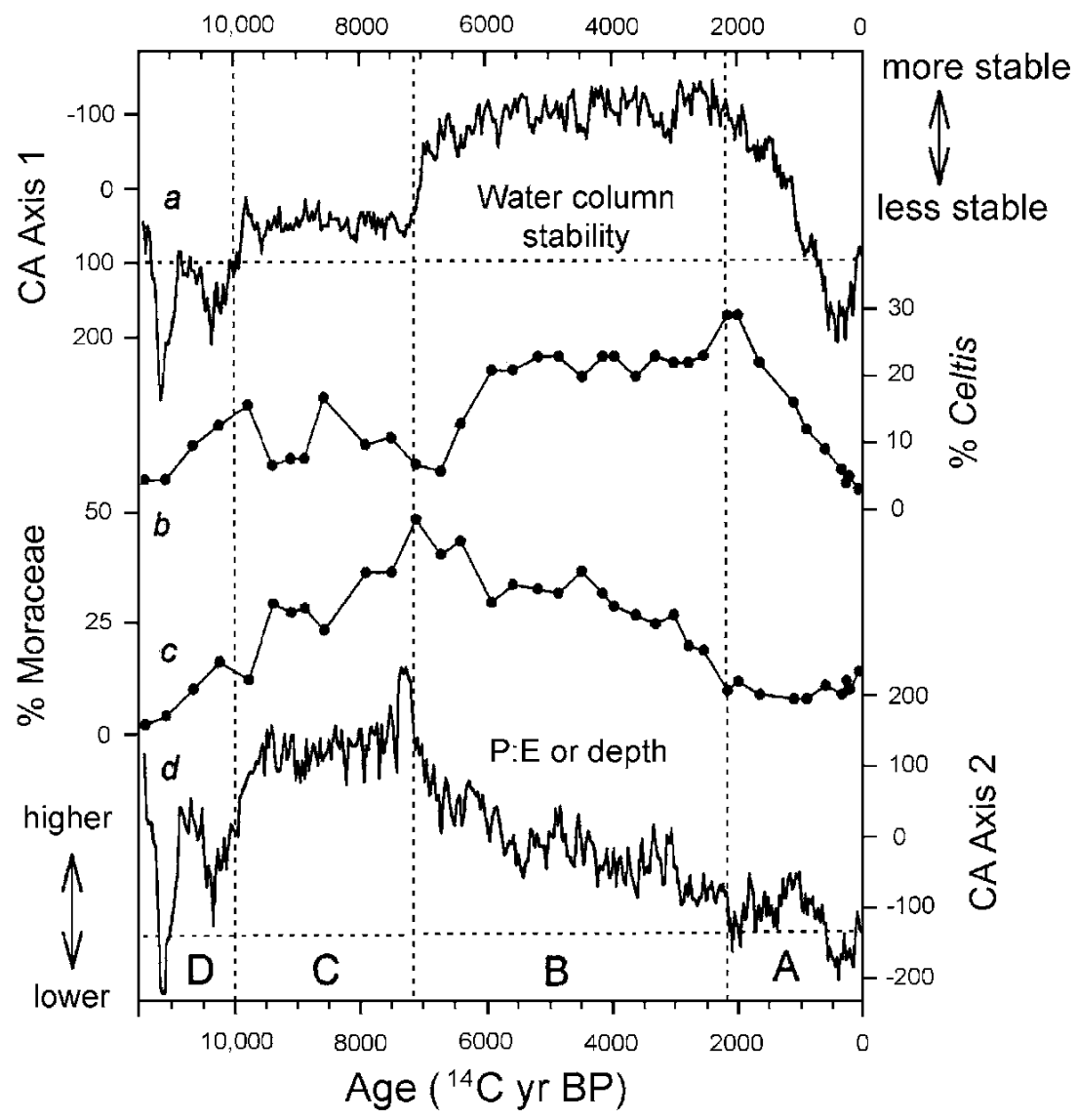

Figure 6. Trends in correspondence analysis (CA) axis-1 and -2 sample scores of fossil diatom assemblages from Lake Victoria's Damba Channel (East Africa) over the past 11,000 years, in relation to changes in the regional abundance of Celtis (reflecting seasonally dry forest) and Moraceae (reflecting moist forest) as reconstructed at a nearby location in Lake Victoria from fossil pollen. (From Stager et al. 1997, with permission.)

Aulacoseira species, that prefer well-mixed deep water, coincident with high abundances of pollen from humid forest trees (e.g., Moraceae); (3) a period of increased seasonality beginning $\sim 7900$ cal year BP characterized by high abundances of taxa that thrive under enhanced thermal stratification, including $A$. nyassensis and Nitzschia taxa, coincident with evidence of seasonally dry forests (e.g., Celtis); and (4) a late-Holocene period (from 2300 cal year BP) of increasing aridity characterized by a return to higher abundances of Fragilaria taxa, benthic diatoms, and grasses and phytoliths (Stager et al. 1997). Virtually identical interpretations have been presented for two other cores from Lake Victoria, one from the center of the lake (Stager and Johnson 2000) and one from a shallow peripheral basin (Stager et al. 2003). 


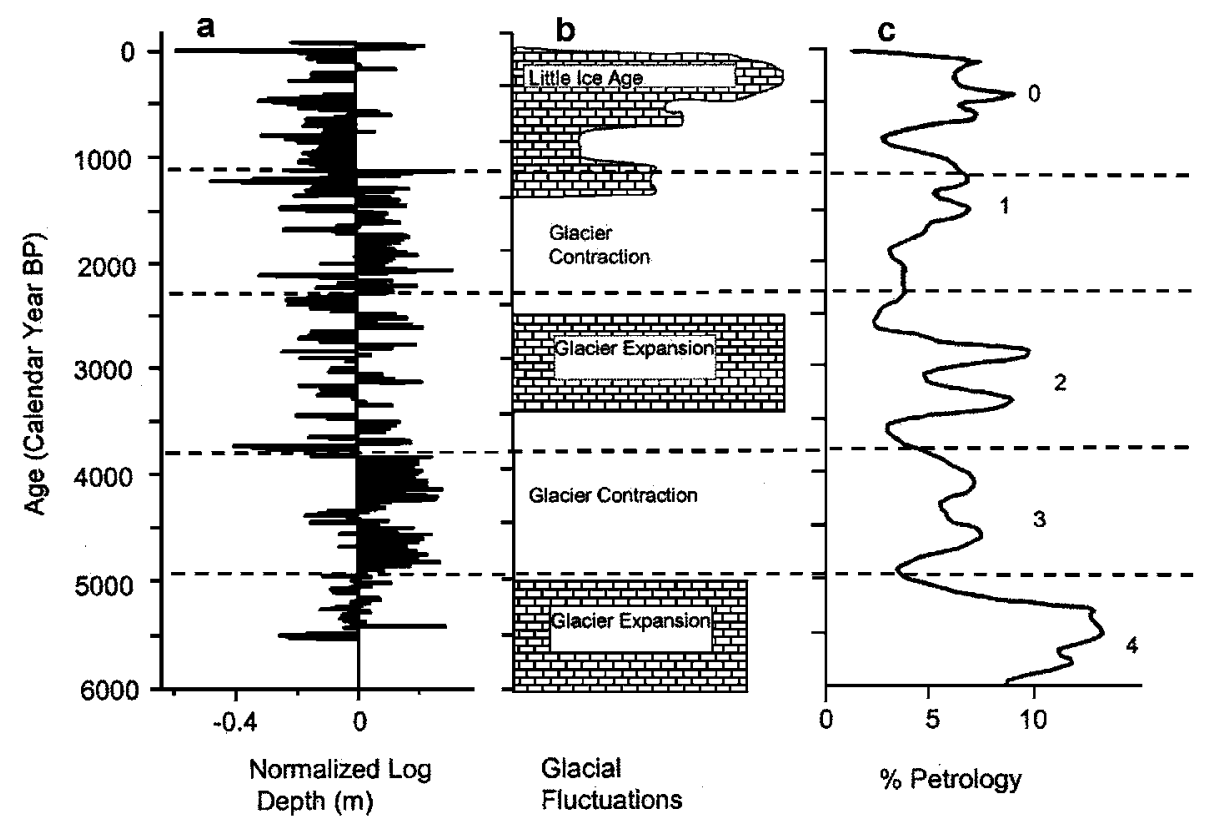

Figure 7. Relationship between (a) diatom-inferred changes in lake depth at Big Lake (British Columbia, Canada) over the past 5500 years and (b) a summary of world-wide glacier fluctuations (Denton and Karlen 1973), and (c) a composite record of ice-rafted-debris (IRD) in the North Atlantic Ocean (Bond et al. 2001). (Modified from Cumming et al. 2002.)

In a study of multi-decadal to millennium-scale climate dynamics in British Columbia (Canada) since the renewal of glacial activity $\sim 5500$ years ago, Cumming et al. (2002) recorded major shifts in diatom assemblages and diatom-inferred depth and salinity, corresponding well with millennial-scale variations in the expansion/recession of continental glaciers in the region, as well as with ice-rafting events in the North Atlantic Ocean (Figure 7). This result provides supporting evidence for the sensitivity of such lake systems to broad-scale climatic forcing. However, it has been suggested that reconstructions of lake depth from biological assemblages based on regional calibration-sets, as was done in this study (Figure 7), may need to be interpreted with caution because the specific morphometric features of the study lake may not be adequately represented by a regional reference data-set. Birks (1998) suggested that calibration models for lake depth may be best developed on the basis of surface-sediment samples from different depth transects within the lake under investigation. Laird et al. (2011) provide a summary of how quantitative techniques and selection of sensitive near-shore coring locations can be exploited to produce high-resolution paleoclimatic reconstructions. This approach can yield valuable insights, but has an increased risk of non-analogue situations, in which the dominant species in certain sections of the core profile are not represented in the local surface-sediments today. Consequently, in many instances the reconstruction of a limnologi- 
cally important variable, such as lake depth, can benefit from modern calibrationsets that include both surface-sediment samples from within the lake under study (i.e., a transect across depth) as well as in many lakes across the modern landscape. In some cases, quantitative reconstructions of lake-level change using biotic indicators can be constrained by geophysical or geomorphic data that provide clear physical evidence of lake stage at given points in time. This approach has been used in studies of Quaternary lake-level variation in Lake Malawi in Africa (Stone et al. 2011), where a multi-proxy reconstruction of lake level was compared with seismic data; and in a comparison of diatom-inferred conductivity as a proxy for precipitation minus evapotranspiration in West Greenland with dated Holocene paleoshorelines (Aebly and Fritz 2009).

Finally, several studies from Europe have compared quantitative reconstructions of temperature with other regional reconstructions of temperature change. Korhola et al. (2002) used both a Bayesian multinomial model and a weightedaveraging partial least squares model (see Juggins and Birks 2012: ch. 14) to reconstruct temperature based on chironomid assemblages over the Holocene. The results generally agreed with inferences from the Greenland ice-cores and marine sediments, as well as with previous reconstructions from diatoms and pollen (Korhola et al. 2002). Ampel et al. (2010) used a diatom calibration-function at a site in eastern France to quantify the magnitude of summer temperature change associated with millennial events during the late Pleistocene and compared it with other proxy data from the same site, other regional records, and the patterns of variation manifested in the Greenland ice core.

\section{Quantitative Validation of Biological Proxies Using Independent Evidence of Climatic Change}

A number of studies have attempted a quantitative assessment of how much of the variation in biological climate-proxy assemblages can be attributed to climatic forcing, using ordination and partial ordination techniques including VPA. For example, in an 1100-year lake record from northern Sweden, Anderson et al. (1996) (see also Lotter and Anderson 2012: ch. 18) found a weak relationship between changes in diatom species assemblages and tree-ring inferred estimates of summer temperature. However, this relationship could only explain $5.2 \%$ of the variation in the diatom assemblages, and only after the temperature data were lagged by 20 years. Interestingly, a stronger relationship ( 10\% of the observed variation) was found between species richness and temperature. Other investigators have used VPA to compare the relative importance of climate and other factors contributing to changes in biological assemblages. For example, Birks and Lotter (1994) and Lotter et al. (1995) attempted to disentangle the impacts of volcanic tephra and climatic change on terrestrial and aquatic ecosystems (see Lotter and Anderson 2012: ch. 18). Similarly, Barker et al. (2000) used VPA to investigate the relative importance of climate (represented by the ratio between tree 
and grass pollen), catchment disturbance (represented by magnetic properties of the sediments), and tephra deposition on a 4100-year diatom record from Lake Massoko (southern Tanzania). The effects of time-dependent ecological and environmental processes were removed by using sample age as a covariable in partial constrained ordination (see Legendre and Birks 2012: ch. 8). Anderson et al. (2008) used independent climatic data (e.g., Greenland ice-core data) to assess the degree to which climate versus in-lake processes explained the community structure of chironomids and other proxies. In this study, catchment changes or biotic relationships explained more variation than Holocene climate, with the exception of the early lake development. VPA also has been used to demonstrate that changes in land-use have been more important than climate in driving changes in the diatom flora of Seebergsee (Switzerland) over the last 2600 years (Hausmann et al. 2002). A recurring theme in many of these studies is that, although climatic forcing has accounted for a significant fraction of the reconstructed biological variation, the amount of variation explained by climate alone, over the time scales examined, has been relatively small.

\section{Other Numerical Techniques Used in Lake-Based Studies of Climatic Change}

As is clear from the material discussed above, calibration functions, ordination, and regression techniques are the methods most commonly used to track paleoclimatic signals in biological and other proxies extracted from lake sediments. Calibration functions are continually being tested and refined (e.g., Köster et al. 2004; Eggermont et al. 2006; Battarbee et al. 2008; Birks et al. 2010), and new numerical approaches continue to be developed (e.g., Racca et al. 2003; Hübener et al. 2008). Many examples of these techniques are presented above, and/or are covered in detail in Parts II-IV of this book [H.J.B. Birks, et al., eds., Tracking Environmental Change Using Lake Sediments (2012)]. Methods based on aquatic algae have also been summarized in Smol and Cumming (2000), as well as in more detailed accounts of paleoclimatic techniques for semi-arid regions (Bradbury 1999; Fritz 2008; Fritz et al. 2010) and arctic and alpine regions (Smol and Douglas 2007; Douglas and Smol 2010; Lotter et al. 2010). Additionally, there have been substantial developments in the application of chironomids and cladocerans as quantitative indicators of past climatic conditions (e.g., Lotter et al. 1997; Larocque et al. 2001; Korhola et al. 2002; Palmer et al. 2002; Heiri et al. 2004; von Gunten et al. 2008; Eggermont et al. 2008; Kröpelin et al. 2008). For example, Palmer et al. (2002) provided a midge-based consensus reconstruction of Holocene mean July air temperatures for southern British Columbia (Canada) based on sediment cores from four lake sites.

Although the number of lake-based quantitative paleoenvironmental reconstructions has increased rapidly in the past decade, for some time relatively little attention was given to a thorough evaluation and validation of these reconstructions (Birks 1998). This has now improved with the availability of a number of simple approaches to assess the basic reliability of environmental reconstructions (Telford and Birks 2011). For example, Laird et al. (1998a) assessed the reliability 
of the Moon Lake salinity inferences over the past 2300 years (Laird et al. 1996a) (Figure 8) by (1) calculating how well a "fossil" sample is represented by modern assemblages (Figure $8 \mathrm{~b}$ ), and (2) assessing the overall "goodness-of fit" of the environmental reconstruction (Figure 8c). The lower the dissimilarity coefficient or the less often a sample is in the extreme of the distribution of the "goodness-offit," the more confidence one can place in a reconstructed value, because the "fossil" assemblages are well represented in the modern data-set (Birks et al. 1990). For their paleosalinity reconstructions based on African chironomid assemblages, Verschuren et al. (2004) and Eggermont et al. (2006) additionally assessed to what extent numerical differences between calibration functions affected reconstructed salinity trends through time. Initially this was deemed necessary because, lacking a traditional calibration data-set of faunal composition based on surface-sediment assemblages, Verschuren et al. (2000b) had performed a hybrid procedure in which a weighted-averaging (WA) inference model calibrated with presence/ absence distributional records from the literature was applied to abundanceweighted fossil data. This helped ensure that changes in the relative abundance between taxa, not just their new appearance or complete disappearance, would generate a proxy climatic signal. Verschuren et al. (2004) justified this hybrid procedure by proposing that calibration based on presence/absence data is not dissimilar to an abundance-weighted calibration with down-weighting of rare taxa. Using (semi-) independent paleohydrological reconstructions based on sediment stratigraphy and fossil diatom assemblages (Verschuren et al. 2000b) as a reference framework, coupled with a consideration of modern-day benthic community dynamics in shallow closed-basin African lakes, Eggermont et al. (2006) documented significant variation among calibration functions in reconstructed salinity trends, mainly reflecting their different sensitivity to the presence or relative abundance of certain key taxa. Specifically, WAPLS and maximum likelihood (ML) techniques statistically "camouflage" the step change in chironomid faunal composition near the freshwater-saline boundary, resulting in less robust reconstructions. These authors concluded that selection of the most appropriate calibration function for environmental reconstruction should not solely optimize the statistical performance of the resulting inference model, but carefully consider whether it produces ecologically meaningful reconstruction results with high signal content (see Juggins and Birks 2012: ch. 14).

Confidence in paleoclimatic inferences will also further increase as broadscale patterns are replicated in space and time. Examples of coherence are starting to emerge at a number of sites, over different temporal and spatial scales, for example, the studies by Sorvari et al. (2002) and Palmer et al. (2002) discussed above. Similarly, several studies (Fritz et al. 2000; Yu et al. 2002; Laird et al. 2003; Schmieder et al. 2011) have presented strong evidence of synchronous changes at various sites in the Great Plains of North America over the last 1500-2000 years.

A number of studies of climatic change have begun to address ecologically interesting questions that attempt to assess changes in stability and diversity (e.g., Anderson et al. 1996; Laird et al. 1998a, 1998b; Wolfe 2003; Stone and Fritz 2006; Hobbs et al. 2010). For example, Laird et al. (1996a, 1998a) found a large switch 

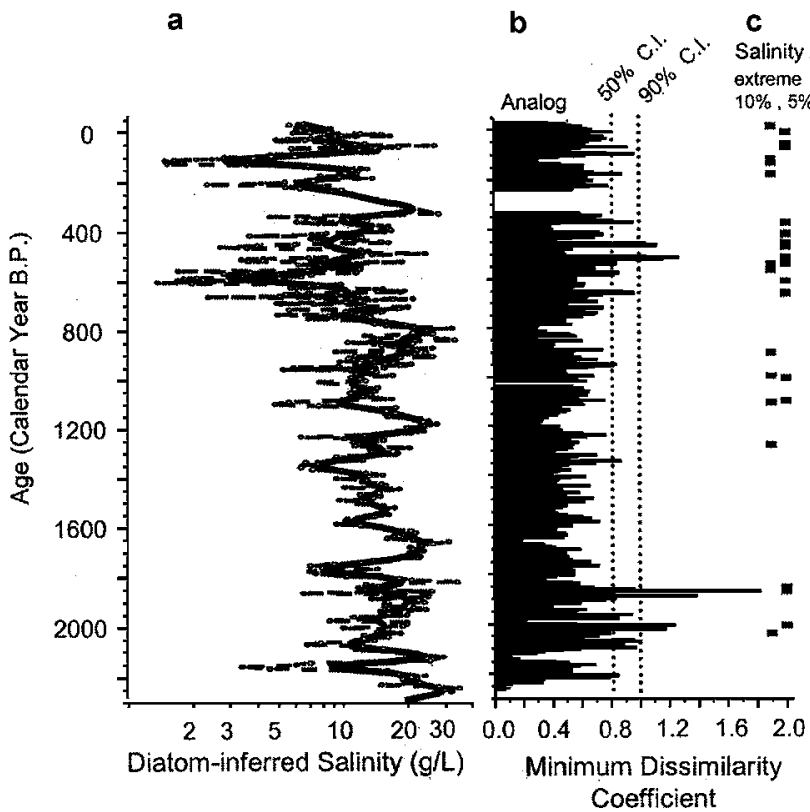

d
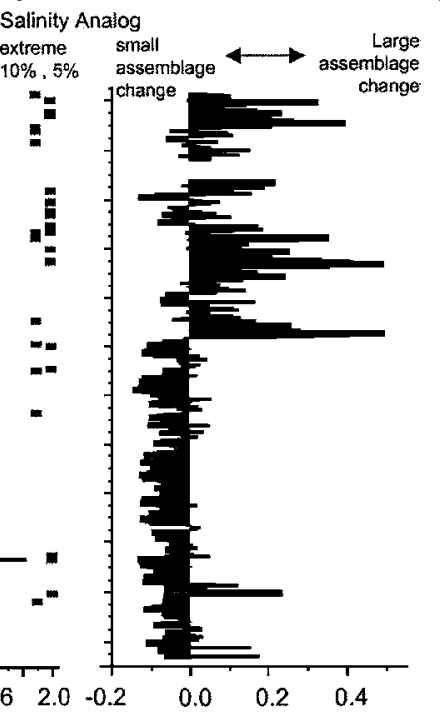

Deviation from Mean Chord Distancè/5 Years

Figure 8. (a) Diatom-inferred salinity changes at Moon Lake (North Dakota, USA) over the last 2200 years. (b) Analogue analysis and (c) "goodness-of-fit" analyses based on comparisons between dissimilarities between core and modern diatom assemblages, and diagnostics from a constrained ordination, respectively (see text for details). (d) The results of a rate-of-change analysis used to assess changes in community stability. (Modified from Laird et al. 1998a.)

in inferred climatic conditions in the record from Moon Lake (North Dakota, USA) indicated by a distinct change in inferred salinity before and after AD 1200 (Figure 8a). The differences in the environmental stability of Moon Lake before and after $\sim \mathrm{AD} 1200$ were assessed by estimating the rate-of-change in the diatom assemblages, based on a dissimilarity coefficient between adjacent samples over a fixed time interval (see Birks 2012: ch. 11). The results of this analysis suggested that the diatom assemblages in Moon Lake were significantly more stable prior to AD 1200 (during a period of inferred prolonged aridity) than for the last $\sim 800$ years, which were relatively wet (Figure $8 \mathrm{~d}$ ). This approach has also been employed to assess changes in limnological stability between the earlyand late-Holocene (Laird et al. 1998b; Clark et al. 2002), and through periods of Holocene cooling and warming (Anderson et al. 1996; Palmer et al. 2002; Wolfe 2003). Heegaard et al. (2006) used cumulative rate-of-change and cumulative relative rate-of-change to assess the detection of aquatic ecotones along an altitudinal gradient in the Swiss Alps for cladocera, chironomids, and diatoms. Assessing changes in biological richness and diversity has become a topic of renewed interest in paleolimnological studies. For example, Sorvari et al. (2002) noticed a decline in richness (estimated as Hill's (1973) N2, a measure of richness of common 
species) coincident with the recent inferred warming of lakes in Finnish Lapland. A significant negative correlation between diatom richness and temperature was also found in northern Sweden (Anderson et al. 1996). Conversely, Wolfe (2003) showed that richness increased following climatic deterioration from the climatic optimum, which started $\sim 2000$ years BP.

In the complex system of the Mackenzie River and Slave River delta systems, species richness and "indicator" taxa were used to distinguish between three hydrologically distinct lake types (Hay et al. 2000; Sokal et al. 2008). Ordination methods were first used to assess the distribution of diatom assemblages in the three lake categories. Sokal et al. (2008) then used analysis of similarities (ANOSIM: Clarke and Warwick 2001) to test whether the diatom assemblages differed significantly among the three lake categories in the Slave River Delta. Finally, similarity percentage tests (SIMPER: Clarke and Gorley 2006) were performed to identify specific diatom taxa that accounted for these differences and canonical variates analysis was used to assess whether "indicator" taxa significantly discriminate the hydrological lake categories (Sokal et al. 2008). These studies indicate that numerical methods can be used to assess the hydrological and climatic variability within complex delta systems.

Finally, it is becoming increasingly evident that the temporal structure of many paleolimnological records is composed of periodic components. Correct identification of these periodicities and how they vary over time is becoming increasingly important in paleolimnological studies. Aspects of this critical topic are covered in Dutilleul et al. (2012: ch. 16).

Acknowledgement - We would like to thank H.J.B. Birks for suggesting that we write this review. His interest and involvement in a wide array of ecological, paleoecological, and statistical issues continue to serve as a source of inspiration.

\section{References}

Aebly F, Fritz SC (2009) Palaeohydrology of Kangerlussuaq (Søndre Strømfjord), West Greenland during the last 8000 years. Holocene 19:91-104

Agusti-Panareda A, Thompson R (2002) Reconstructing air temperatures at eleven remote alpine and arctic lakes in Europe from 1781 to 1997 AD. J Paleolimnol 28:7-23

Ampel L, Bigler C, Wolfarth B, Risberg J, Lotter AF, Veres D (2010) Modest summer temperature variability during DO cycles in western Europe. Quaternary Sci Rev 29:1322-1327

Anderson NJ, Odgaard BV, Segerström U, Renberg I (1996) Climate-lake interactions recorded in varved sediments from a Swedish boreal forest lake. Glob Change Biol 2:399-405

Anderson NJ, Brodersen KP, Ryves DB, McGowan S, Johansson LS, Jeppesen E, Leng MJ (2008) Climate versus in-lake processes as controls on the development of community structure in a low-arctic lake (south-west Greenland). Ecosystems 11:307-324

Baker PA, Seltzer GO, Fritz SC, Dunbar RB, Grove MJ, Tapia PM, Cross SL, Rowe HD, Broda JP (2001) The history of South American tropical precipitation for the past 25,000 years. Science 291:640-643

Barker P, Telford RJ, Merdaci O, Williamson D, Taieb M, Vincens A, Gilbert E (2000) The sensitivity of a Tanzanian crater lake to catastrophic tephra input and four millennia of climate change. Holocene 10:303-310 
Battarbee RW (2000) Palaeolimnological approaches to climate change, with special regard to the biological record. Quaternary Sci Rev 19:107-124

Battarbee RW, Grytnes J-A, Thompson R, Appleby PG, Catalan J, Korhola A, Birks HJB, Heegaard E, Lami A (2002a) Comparing palaeolimnological and instrumental evidence of climate change for remote mountain lakes over the last 200 years. J Paleolimnol 28:161-179

Battarbee RW, Thompson R, Catalan J, Grytnes J-A, Birks HJB (2002b) Climate variability and ecosystem dynamics of remote alpine and arctic lakes: The MOLAR project. J Paleolimnol 28:1-6

Battarbee RW, Monteith DT, Juggins S, Simpson GL, Shilland EW, Flower RJ, Kreiser $\operatorname{AM}(2008)$ Assessing the accuracy of diatom-based transfer functions in defining reference conditions for acidified lakes in the United Kingdom. Holocene 18:57-67

Bennett JR, Cumming BF, Leavitt PR, Chiu M, Smol JP, Szeicz J (2001) Diatom, pollen, and chemical evidence of postglacial climatic change at Big Lake, south-central British Columbia, Canada. Quaternary Res 55:332-343

Bigler C, Hall RI (2003) Diatoms as quantitative indicators of July temperature: A validation attempt at century-scale with meteorological data from northern Sweden. Palaeogeogr Palaeoclim Palaeoecol 189:147-160

Birks HJB (1998) Numerical tools in palaeolimnology - Progress, potentialities, and problems. J Paleolimnol 20:307-332

Birks HJB (2012) Chapter 11: Analysis of stratigraphical data. In: Birks HJB, Lotter AF, Juggins S, Smol JP (eds.) Tracking environmental change using lake sediments. Volume 5: Data handling and numerical techniques. Springer, Dordrecht

Birks HJB, Lotter AF (1994) The impact of the Laacher See Volcano (11000 years BP) on terrestrial vegetation and diatoms. J Paleolimnol 11:313-322

Birks HJB, Line JM, Juggins S, Stevenson AC, ter Braak CJF (1990) Diatoms and pH reconstructions. Philos Trans R Soc Lond B 327:263-278

Birks HJB, Heiri O, Seppä H, Bjune AE (2010) Strengths and weaknesses of quantitative climate reconstructions based on late-Quaternary biological proxies. Open Ecol J 3:68-110

Bond G, Kromer B, Beer J, Muscheler R, Evans MN, Showers W, Hoffmann S, Lotti-Bond R, Hajdas I, Bonani G (2001) Persistent solar influence on north Atlantic climate during the Holocene. Science 294:2130-2136

Borcard D, Legendre P, Drapeau P (1992) Partialling out the spatial component of ecological variation. Ecology 73:1045-1055

Bradbury JP (1999) Continental diatoms as indicators of long-term environmental change. In: Smol JP, Stoermer EF (eds.) The diatoms: Applications for the environmental and earth sciences. Cambridge University Press, Cambridge, pp 169-182

Bradbury P, Cumming B, Laird K (2002) A 1500-year record of climatic and environmental change in Elk Lake, Minnesota III: Measures of past primary productivity. J Paleolimnol 27:321-340

Brodersen KP, Anderson NJ (2002) Distribution of chironomids (Diptera) in low Arctic west Greenland lakes: Trophic conditions, temperature and environmental reconstruction. Freshw Biol 47:1137-1157

Catalan J, Plas S, Rieradevall M, Felip M, Ventura M, Buchaca T, Camarero L, Brancelj A, Appleby PG, Lami A, Grytnes J-A, Agusti-Panareda A, Thompson R (2002) Lake Redó ecosystem response to an increasing warming in the Pyrenees during the twentieth century. J Paleolimnol 28:129-145

Clark JS, Grimm EC, Donovan JJ, Fritz SC, Engstrom DR, Almendinger JE (2002) Drought cycles and landscape responses to past aridity on prairies of the northern Great Plains, USA. Ecology 83:595-601

Clarke KR, Gorley RN (2006) PRIMER v6: User manual/tutorial. PRIMER-E, Plymouth

Clarke KR, Warwick RM (2001) Change in marine communities: An approach to statistical analysis and interpretation, 2nd ed. PRIMER-E, Plymouth 
Cumming BF, Moser KA (2007) Applications of commonly used numerical techniques in diatom-based paleoecology. Paleontol Soc Pap 13:37-56

Cumming BF, Laird KR, Bennett JR, Smol JP, Salomon AK (2002) Persistent millennialscale shifts in moisture regimes in western Canada during the past six millennia. Proc Natl Acad Sci USA 99:16117-16121

Dean WE (2002) A 1500-year record of climatic and environmental change in Elk Lake, Clearwater County, Minnesota II: Geochemistry, mineralogy, and stable isotopes. J Paleolimnol 27:301-319

Dean WE, Anderson RY, Bradbury JP (2002) A 1500-year record of climatic and environmental change in Elk Lake, Minnesota - I: Varve thickness and gray-scale density. J Paleolimnol 27:287-299

Denton GH, Karlen W (1973) Holocene climatic variations - their pattern and possible cause. Quaternary Res 3:155-205

Donovan JJ, Smith AJ, Panek VA, Engstrom DR, Ito E (2002) Climate-driven hydrologic transients in lake sediment records: Calibration of groundwater conditions using 20th century drought. Quaternary Sci Rev 21:605-624

Doran PT, Priscu JC, Lyons WB, Walsh JE, Fountain AG, McKnight DM, Moorhead DL, Virginia RA, Wall DH, Clow GD, Fritsen CH, McKay CP, Parsons AN (2002) Antarctic climate cooling and terrestrial ecosystem response. Nature 415:517-520

Douglas MSV, Smol JP (2010) Freshwater diatoms as indicators of environmental change in the high arctic. In: Smol JP, Stoermer EF (eds.) The diatoms: Applications for the environmental and earth sciences, 2nd ed. Cambridge University Press, Cambridge, pp 249-266

Dutilleul P, Cumming BF, Lontoc-Roy M (2012) Chapter 16: Autocorrelogram and periodogram analysis of palaeolimnological temporal series from lakes in central and western North America to assess shifts in drought conditions. In: Birks HJB, Lotter AF, Juggins S, Smol JP (eds.) Tracking environmental change using lake sediments. Volume 5: Data handling and numerical techniques. Springer, Dordrecht

Eggermont H, Heiri O, Verschuren D (2006) Fossil Chironomidae (Insecta: Diptera) as quantitative indicators of past salinity in African lakes. Quaternary Sci Rev 25:1966-1994

Eggermont H, Verschuren D, Fagot M, Rumes B, Van Bocxlaer B, Kröpelin S (2008) Aquatic community response in a groundwater-fed desert lake to Holocene desiccation of the Sahara. Quaternary Sci Rev 27:2411-2425

Eggermont H, Verschuren D, Audenaert L, Lens L, Russell J, Klaassen G, Heiri O (2010a) Limnological and ecological sensitivity of Rwenzori mountain lakes to climate warming. Hydrobiologia 648:123-142

Eggermont H, Heiri O, Russell J, Vuille M, Audenaert L, Verschuren D (2010b) Paleotemperature reconstruction in tropical Africa using fossil Chironomidae (Insecta: Diptera). J Paleolimnol 43:413-435

Enache MD, Cumming BF (2009) Extreme fires under warmer and drier conditions inferred from sedimentary charcoal morphotypes from Opatcho Lake, central British Columbia, Canada. Holocene 19:835-846

Engstrom DR, Nelson S (1991) Palaeosalinity from trace metals in fossil ostracods compared with observational records at Devils Lake, North Dakota, USA. Palaeogeogr Palaeoclim Palaeoecol 83:295-312

Fritz SC (1990) Twentieth-century salinity and water-level fluctuations in Devils Lake, North Dakota: Test of a diatom-based transfer function. Limnol Oceanogr 35:1171-1781

Fritz SC (1996) Palaeolimnological records of climate change in North America. Limnol Oceanogr 41:882-889

Fritz SC (2008) Deciphering climatic history from lake sediments. J Paleolimnol 39:5-16

Fritz SC, Ito E, Yu Z, Laird KR, Engstrom DR (2000) Hydrologic variation in the northern Great Plains during the last two millennia. Quaternary Res 53:175-184 
Fritz SC, Cumming BF, Gasse F, Laird KR (2010) Diatoms as indicators of hydrologic and climatic change in saline lakes. In: Smol JP, Stoermer EF (eds.) The diatoms: Applications for the environmental and earth sciences, 2nd ed. Cambridge University Press, Cambridge, pp 186-208

Gajewski K (2008) The global pollen database in biogeographical and paleoclimatic studies. Progr Phys Geog 32:379-402

Hall RI, Leavitt PR, Quinlan R, Dixit AS, Smol JP (1999) Effects of agriculture, and climate on water quality in the northern Great Plains. Limnol Oceanogr 44:739-756

Harrison SP, Digerfeldt G (1993) European lakes as palaeohydrological and paleoclimatic indicators. Quaternary Sci Rev 12:233-248

Hausmann S, Lotter AF, van Leeuwen JFN, Ohlendorf C, Lemcke G, Gronlund E, Strum $\mathrm{M}(2002)$ Interactions of climate and land use documented in the varved sediments of Seebergsee in the Swiss Alps. Holocene 12:279-289

Hay MB, Michelutti N, Smol JP (2000) Ecological patterns of diatom assemblages from Mackenzie Delta lakes, Northwest Territories, Canada. Can J Bot 78:19-33

Heegaard E, Lotter AF, Birks HJB (2006) Aquatic biota and the detection of climate change: Are there consistent aquatic ecotones? J Paleolimnol 35:507-518

Heiri O, Lotter AF (2005) Holocene and late-glacial summer temperature reconstruction in the Swiss Alps based on fossil assemblages of aquatic organisms: A review. Boreas 34:506-516

Heiri O, Tinner W, Lotter AF (2004) Evidence for cooler European summers during periods of changing meltwater flux to the North Atlantic. Proc Natl Acad Sci USA 101:15285-15288

Hernandez A, Giralt S, Bao R, Saez A, Leng MJ, Barker PA (2010) ENSO and solar activity signals from oxygen isotopes in diatom silica during late glacial-Holocene transition in Central Andes (18 ${ }^{\circ}$ ). J Paleolimnol 44:413-429

Hill MO (1973) Diversity and evenness: A unifying notation and its consequences. Ecology 54:427-431

Hobbs WO, Telford R, Birks HJB, Saros J, Hazewinkel R, Perren B, Saulnier E, Wolfe A (2010) Quantifying recent ecological changes in remote lakes of North America and Greenland using sediment diatom assemblages. PLoS One 5:e10026

Hübener T, Dreßler M, Schwarz A, Langner K, Adler S (2008) Dynamic adjustment of training sets ('moving-window' reconstruction) by using transfer functions in paleolimnology - A new approach. J Paleolimnol 40:79-95

Interlandi SJ, Kilham SS, Theriot EC (1999) Responses of phytoplankton to varied resource availability in large lakes of the Greater Yellowstone Ecosystem. Limnol Oceanogr 44: 668-682

Juggins S, Birks HJB (2012) Chapter 14: Quantitative environmental reconstructions from biological data. In: Birks HJB, Lotter AF, Juggins S, Smol JP (eds.) Tracking environmental change using lake sediments. Volume 5: Data handling and numerical techniques. Springer, Dordrecht

Kendall RL (1969) An ecological history of the Lake Victoria basin. Ecol Monogr 39:121-176

Koinig KA, Kamenik C, Schmidt R, Agusti-Panareda A, Appleby PG, Lami A, Prazakova M, Rose N, Schnell OA, Tessadri R, Thompson R, Psenner R (2002) Environmental changes in an alpine lake (Gossenkollesee, Austria) over the last two centuries the influence of air temperature on biological parameters. J Paleolimnol 28:147-160

Korhola A (1999) Distribution patterns of Cladocera in subarctic Fennoscandian lakes and their potential in environmental reconstruction. Ecography 22:357-373

Korhola A, Rautio M (2001) Cladocera and other small brachiopods. In: Smol JP, Birks HJB, Last WM (eds.) Tracking environmental change using lake sediments. Volume 4: Zoological indicators. Kluwer Academic Publishers, Dordrecht, pp 5-41

Korhola A, Vasko K, Toivonen HTT, Olander H (2002) Holocene temperature change in northern Fennoscandia reconstructed from chironomids using Bayesian modelling. Quaternary Sci Rev 21:1841-1860 
Köster D, Racca JMJ, Pienitz R (2004) Diatom-based inference models and reconstructions revisited: Methods and transformations. J Paleolimnol 32:233-246

Kröpelin S, Verschuren D, Lézine AM, Eggermont H, Cocquyt C, Francus P, Cazet J-P, Fagot M, Rumes B, Russell JM, Conley S, Schuster M, von Suchodoletz H, Engstrom DR (2008) Climate-driven ecosystem succession in the central Sahara: The last 6000 years. Science 320:765-768

Laird KR, Fritz SC, Grimm EC, Mueller PG (1996a) Century-scale paleoclimatic reconstruction from Moon Lake, a closed-basin lake in the northern Great Plains. Limnol Oceanogr 41: 890-902

Laird KR, Fritz SC, Maasch KA, Cumming BF (1996b) Greater drought intensity and frequency before AD 1200 in the northern Great Plains, USA. Nature 384:552-554

Laird KR, Fritz SC, Cumming BF (1998a) A diatom-based reconstruction of drought intensity, duration, and frequency from Moon Lake, North Dakota: A sub-decadal record of the last 2300 years. J Paleolimnol 19:161-179

Laird KR, Fritz SC, Cumming BF (1998b) Early-Holocene limnological and climatic variability in the northern Great Plains. Holocene 8:275-286

Laird KR, Cumming BF, Wunsam S, Rusak J, Oglesby RJ, Fritz SC, Leavitt PR (2003) Largescale shifts in moisture regimes from lake records across the northern prairies of North America during the past two millennia. Proc Natl Acad Sci USA 100:2483-2488

Laird KR, Kingsbury MV, Lewis CFM, Cumming BF (2011) Diatom-inferred depth models in 8 Canadian boreal lakes: Inferred changes in the benthic:planktonic depth boundary in northwestern Ontario over the Holocene. Quaternary Sci Rev 30:1201-1217

Lamb HF, Darbyshire I, Verschuren D (2003) Vegetation response to rainfall variation and human impact in central Kenya during the past 1100 years. Holocene 13:285-292

Lamoureux S (2000) Five centuries of interannual sediment yield and rainfall-induced erosion in the Canadian high arctic recorded in lacustrine varves. Water Res 36:309-318

Larocque I, Hall RI (2003) Chironomids as quantitative indicators of mean July air temperature: Validation by comparison with century-long meteorological records from northern Sweden. J Paleolimnol 29:475-493

Larocque I, Hall RI, Grahn E (2001) Chironomids as indicators of climate change: A 100 lake training set from a subarctic region of northern Sweden (Lapland). J Paleolimnol 172:133-142

Legendre P, Birks HJB (2012) Chapter 8: From classical to canonical ordination. In: Birks HJB, Lotter AF, Juggins S, Smol JP (eds.) Tracking environmental change using lake sediments. Volume 5: Data handling and numerical techniques. Springer, Dordrecht

Legesse D, Gasse F, Radakovitch O, Vallet-Coulomb C, Bonnefille R, Verschuren D, Gibert E, Barker P (2002) Environmental changes in a tropical lake (Lake Abiyata, Ethiopia) during recent centuries. Palaeogeogr Palaeoclim Palaeoecol 187:233-258

Lotter AF (1998) The recent eutrophication of Baldeggersee (Switzerland) as assessed by fossil diatom assemblages. Holocene 8:95-405

Lotter AF, Anderson NJ (2012) Chapter 18: Limnological responses to environmental changes at inter-annual to decadal time-scales. In: Birks HJB, Lotter AF, Juggins S, Smol JP (eds.) Tracking environmental change using lake sediments. Volume 5: Data handling and numerical techniques. Springer, Dordrecht

Lotter AF, Birks HJB (1997) The separation of the influence of nutrients and climate on the varve time-series of Baldeggersee, Switzerland. Aquat Sci 59:362-375

Lotter AF, Birks HJB, Zolitschka B (1995) Late-glacial pollen and diatom changes in response to two different environmental perturbations: Volcanic eruption and Younger Dryas cooling. J Paleolimnol 14:23-47

Lotter AF, Birks HJB, Hofmann W, Marchetto A (1997) Modern diatom, cladocera, chironomid and chrysophyte cyst assemblages as quantitative indicators for the reconstruction of past environmental conditions in the Alps. I. Climate. J. Paleolimnol 18:395-420 
Lotter AF, Pienitz P, Schmidt R (2010) Diatoms as indicators of environmental change in subarctic and alpine regions. In: Smol JP, Stoermer EF (eds.) The diatoms: Applications for the environmental and earth sciences, 2nd ed. Cambridge University Press, Cambridge, pp 231-248

MacDonald GM, Edwards TWD, Moser KA, Pienitz R, Smol JP (1993) Rapid response of tree-line vegetation and lakes to past climate warming. Nature 361:243-246 Noon PE, Birks HJB, Jones VJ, Ellis-Evans JC (2001) Quantitative models for reconstructing catchment ice-extent using physical-chemical characteristics of lake sediments. J Paleolimnol 25:375-392

Olaka LA, Odada EO, Trauth MH, Olago DO (2010) The sensitivity of East African rift lakes to climate fluctuations. J Paleolimnol 44:629-644

Palmer S, Walker I, Heinrichs M, Hebda R, Scudder G (2002) Postglacial midge community change and Holocene palaeotemperatures reconstructions near treeline, southern British Columbia (Canada). J Paleolimnol 28:469-490

Pienitz R, Smol JP, Birks HJB (1995) Assessment of freshwater diatoms as quantitative indicators of past climatic-change in the Yukon and Northwest Territories, Canada. J Paleolimnol 13: 21-49

Pienitz R, Smol JP, MacDonald GM (1999) Paleolimnological reconstruction of Holocene climatic trends from two boreal treeline lakes, Northwest Territories, Canada. Arct Antarct Alp Res 31:82-93

Pienitz R, Lotter AF, Newman L, Kiefer T (eds.) (2009) Advances in paleolimnology. PAGES News 17:89-136

Prentice IC, Bartlein PJ, Webb T (1991) Vegetation and climate change in eastern North America since the last glacial maximum. Ecology 72:2038-2056

Psenner R, Schmidt R (1992) Climate-driven $\mathrm{pH}$ control of remote alpine lakes and effects of acid deposition. Nature 356:781-783

Quinlan R, Leavitt PR, Dixit AS, Hall RI, Smol JP (2002) Landscape effects of climate, agriculture, and urbanization on benthic invertebrate communities of Canadian prairie lakes. Limnol Oceanogr 47:378-391

Racca JMJ, Wild M, Birks HJB, Prairie YT (2003) Separating wheat from chaff: Diatom taxon selection using an artificial neural network pruning algorithm. J Paleolimnol 29:123-133

Ritchie JC (1987) Postglacial vegetation of Canada. Cambridge University Press, Cambridge SAS Inc (2004) Online Doc 9.1.3. SAS Institute Inc., Cary

Schindler DW, Bayley SE, Parker BR, Beaty KG, Cruikshank DR, Fee EJ, Stainton MP (1996) The effect of climatic warming on the properties of boreal lakes and streams at the Experimental Lakes Area, northwestern Ontario. Limnol Oceanogr 41:1004-1017

Schmieder J, Fritz SC, Swinehart J, Shinneman AC, Wolfe AP, Miller G, Daniels N, Jacobs K, Grimm EC (2011) A regional-scale climate reconstruction of the last 4000 years from lakes in the Nebraska Sand Hills, USA. Quaternary Sci Rev 30:1797-1812

Schwalb A, Dean WE (2002) Reconstruction of hydrological changes and response to effective moisture variations from North-Central USA lake sediments. Quaternary Sci Rev 21: 1541-1554

Simpson GL (2012) Chapter 15: Analogue methods in palaeolimnology. In: Birks HJB, Lotter AF, Juggins S, Smol JP (eds.) Tracking environmental change using lake sediments. Volume 5: Data handling and numerical techniques. Springer, Dordrecht

Simpson GL, Hall IR (2012) Chapter 19: Human impacts-Applications of numerical methods to evaluate surface-water acidification and eutrophication. In: Birks HJB, Lotter AF, Juggins $S$,

Smol JP (eds.) Tracking environmental change using lake sediments. Volume 5: Data handling and numerical techniques. Springer, Dordrecht

Smith LC, Sheng Y, MacDonald GM, Hinzman LD (2005) Disappearing arctic lakes. Science 308:1429 
Smol JP, Cumming BF (2000) Tracking long-term changes in climate using algal indicators in lake sediments. J Phycol 36:986-1011

Smol JP, Douglas MSV (2007) From controversy to consensus: Making the case for recent climatic change in the arctic using lake sediments. Front Ecol Environ 5:466-474

Smol JP, Wolfe AP, Birks HJB, Douglas MSV, Jones VJ, Korhola A, Pienitz R, Ruhland K, Sorvari S, Antoniades D, Brooks SJ, Fallu MA, Hughes M, Keatley BE, Laing TE, Michelutti N, Nazarova L, Nyman M, Paterson AM, Perren B, Quinlan R, Rautio M, Saulnier-Talbot E, Siitoneni S, Solovieva N, Weckstrom J (2005) Climate-driven regime shifts in the biological communities of arctic lakes. Proc Natl Acad Sci USA 102:4397-4402

Sokal MA, Hall RI, Wolfe BB (2008) Relationships between hydrological and limnological conditions in lakes of the Slave River Delta (NWT, Canada) and quantification of their roles on sedimentary diatom assemblages. J Paleolimnol 39:533-550

Sommaruga-Wögrath S, Koinig KA, Schmidt R, Sommaruga R, Tessadri R, Psenner R (1997) Temperature effects on the acidity of remote alpine lakes. Nature 387:64-67

Sorvari S, Korhola A, Thompson R (2002) Lake diatom response to recent Arctic warming in Finnish Lapland. Glob Change Biol 8:171-181

Spooner IS, Mazzucchi D, Osborn G, Gilbert R, Larocque I (2002) A multi-proxy Holocene record of environmental change from the sediments of Skinny Lake, Iskut region, northern British Columbia, Canada. J Paleolimnol 28:419-431

St. Jacques J-M, Cumming BF, Smol JP (2008a) A pre-European settlement pollen-climate calibration set for Minnesota, USA: Developing tools for paleoclimatic reconstructions. J Biogeogr 35:306-324

St. Jacques J-M, Cumming BF, Smol JP (2008b) A 900-year pollen-inferred temperature and effective moisture record from varved Lake Mina, west-central Minnesota, USA. Quaternary Sci Rev 27:781-796

Stager JC, Johnson TC (2000) A 12,400 C-14 yr offshore diatom record form east central Lake Victoria, East Africa. J Paleolimnol 23:373-383

Stager JC, Cumming BF, Meeker L (1997) A high-resolution 11,400-yr diatom record from Lake Victoria, East Africa. Quaternary Res 47:81-89

Stager JC, Cumming BF, Meeker L (2003) A 10,000 year high-resolution diatom record from Pilkington Bay, Lake Victoria, East Africa. Quaternary Res 59:172-181

Stone JR, Fritz SC (2006) Multidecadal drought and Holocene climate instability in the Rocky Mountains. Geology 34:409-412

Stone JR, Westover KS, Cohen A (2011) Late Pleistocene paleohydrography and diatom paleoecology of the central basin of Lake Malawi, Africa. Palaeogeog Palaeoclim Palaeoecol 303:51-70

Telford RJ, Birks HJB (2011) A novel method for assessing the statistical significance of quantitative reconstructions inferred from biotic assemblages. Quaternary Sci Rev 30: 1272-1278

Tierney JE, Russell JM, Huang Y, Sinninghe Damsté JS, Hopmans EC, Cohen AS (2008) Northern hemisphere controls on tropical southeast African climate during the past 60,000 years. Science 322:252-255

Toney J, Huang Y, Fritz SC, Baker PA, Nyren P, Grimm E (2010) Climatic and environmental controls on the occurrence and distribution of long-chain alkenones in lakes of the interior United States. Geochim Cosmchim Acta 74:1563-1578

Verbruggen F, Heiri O, Reichart GJ, Lotter AF (2010) Chironomid $\delta^{18} \mathrm{O}$ as a proxy for past lake water $\delta^{18} \mathrm{O}$ : A Late-glacial record from Rotsee (Switzerland). Quaternary Sci Rev 29: 2271-2279

Verschuren D (1996) Comparative palaeolimnology in a system of four shallow, climatesensitive tropical lake basins. In: Johnson TC, Odada E (eds.) The limnology, climatology and palaeoclimatology of the east African lakes. Gordon and Breach, Newark, pp $559-572$ 
Verschuren D (1999a) Sedimentation controls on the preservation and time resolution of climate-proxy records from shallow fluctuating lakes. Quaternary Sci Rev 18:821-837

Verschuren D (1999b) Influence of depth and mixing regime on sedimentation in a small fluctuating tropical soda lake. Limnol Oceanogr 44:1103-1113

Verschuren D (2001) Reconstructing fluctuations of a shallow East African lake during the past 1800 yrs from sediment stratigraphy in a submerged crater basin. J Paleolimnol 25:297-311

Verschuren D (2003) Lake-based climate reconstruction in Africa: Progress and challenges. Hydrobiologia 500:315-330

Verschuren D, Tibby J, Leavitt PR, Roberts CN (1999a) The environmental history of a climate-sensitive lake in the former 'White Highlands' of central Kenya. Ambio 28:494-501

Verschuren D, Cocquyt C, Tibby J, Roberts CN, Leavitt PR (1999b) Long-term dynamics of algal and invertebrate communities in a small, fluctuating tropical soda lake. Limnol Oceanogr 44:1216-1231

Verschuren D, Tibby J, Sabbe K, Roberts N (2000a) Effects of depth, salinity, and substrate on the invertebrate community of a fluctuating tropical lake. Ecology 81:164-182

Verschuren D, Laird K, Cumming BF (2000b) Rainfall and drought in equatorial East Africa during the past 1,100 years. Nature 403:410-414

Verschuren D, Cumming BF, Laird KR (2004) Quantitative reconstruction of past salinity variations in African lakes using fossil midges (Diptera: Chironomidae): Assessment of inference models in space and time. Can J Fish Aquat Sci 61:986-998

Vinebrooke RD, Hall RI, Leavitt PR, Cumming BF (1998) Fossil pigments as indicators of phototrophic response to salinity and climatic changes in lakes of western Canada. Can J Fish Aquat Sci 55:668-681

von Grafenstein U, Erlenkeuser H, Brauer A, Jouzel J, Johnsen SJ (1999) A mid-European decadal isotope-climate record from 15,500 to 5000 years BP. Science 284:1654-1657

von Gunten L, Heiri O, Bigler C, Casty C, Lotter AF, Sturm M (2008) Seasonal temperatures for the past 400 years reconstructed from diatom and chironomid assemblages in a high-altitude lake (Lej da la Tscheppa, Switzerland). J Paleolimnol 39:283-299

Walker IR (1995) Chironomids as indicators of past environmental change. In: Armitage PD, Cranston PS, Pinder LCV (eds.) The chironomidae. The biology and ecology of nonbiting midges. Chapman \& Hall, London, pp 405-422

Walker IR, Smol JP, Engstrom DR, Birks HJB (1991) An assessment of Chironomidae as quantitative indicators of past climatic change. Can J Fish Aquat Sci 28:975-987

Webb T (1986) Is vegetation in equilibrium with climate? How to interpret late-Quaternary pollen data. Vegetatio 67:75-91

Webster KE, Soranno PA, Baines SB, Kratz TK, Bowser CJ, Dillon PJ, Campbell P, Fee EJ, Hecky RE (2000) Structuring features of lake districts: Landscape controls on lake chemical responses to drought. Freshw Biol 43:499-515

Wolfe AP (2003) Diatom community responses to late-Holocene climatic variability, Baffin Island, Canada: A comparison of numerical approaches. Holocene 13:29-37

Wolfe BB, Edwards TWD, Aravena R, MacDonald GM (1996) Rapid Holocene hydrologic changes along boreal treeline revealed by $\delta^{13} \mathrm{C}$ and $\delta^{18} \mathrm{O}$ in organic lake sediments, Northwest Territories, Canada. J Paleolimnol 15:171-181

Wolin JA, Stone JR (2010) Diatoms as indicators of water-level change in freshwater lakes. In: Smol JP, Stoermer EF (eds.) The diatoms: Applications for the environmental and earth sciences, 2nd ed. Cambridge University Press, Cambridge, pp 174-185

Yu Z, Ito E, Engstrom DR, Fritz SC (2002) A 2100-year trace-element and stable-isotope record at decadal resolution from Rice Lake in the northern Great Plains, USA. Holocene 12: 605-617 